\title{
UDC 595.754 \\ ECOLOGICAL AND FAUNISTIC REVIEW OF THE TRUE BUGS OF INFRAORDER CIMICOMORPHA (HETEROPTERA) OF URBAN CENOSES OF KHARKIV CITY (UKRAINE)
}

\author{
I. A. Fedyay, T. Yu. Markina \\ H. S. Skovoroda Kharkiv National Pedagogical University \\ Alchevskyh st., 29, Kharkiv, 61000 Ukraine \\ E-mail: razira1983@gmail.com \\ E-mail:t.yu.markina@gmail.com \\ I. A Fedyay (http://orcid 0000-0002-7171-1622) \\ T. Yu. Markina (http://orcid 0000-0002-6313-9814); Scopus Researcher ID 56736553600
}

Ecological and Faunistic Review of the True Bugs of Infraorder Cimicomorpha (Heteroptera) of Urban Cenoses of Kharkiv City (Ukraine). Fedyay, I. A., Markina, T. Yu. - A total 69 species from 44 genera and 6 families of the infraorder Cimicomorpha was recorded in urban cenoses of Kharkiv. For the first time Xylocoris galactinus is recorded from Mainland Ukraine; Catoplatus nigriceps and Stenodema holsata - from forest-steppe zone; Trigonotylus ruficornis - from Left-Bank Ukraine. Five species are new to Kharkiv Region. The families Miridae were the richest in species (46) and individual numbers, Nabidae (9) and Tingidae ( 8 species) were less represented. The species composition and individual abundance were the highest in the city parks and green areas of the suburbs, where 38 and 46 species were registered. Within the Forest Park, 29 species were recorded, in floodplain meadows 19 , and in the center of Kharkiv - only 6 species, the number of which was an order of magnitude less than in parks and green areas of the suburbs of the city. In terms of habitat preferences, about 40 species are represented by meadow individuals (almost $60 \%$ of the total number). 10 species are classified as polytopes (more than $8 \%$ ). The forest group is represented by 15 species (about $12 \%$ out of total collected bugs). Among the trophic groups, herbivorous (most of Miridae, Tingidae) and zoophagous of different specializations (Nabidae, Anthocoridae, Reduviidae, some Miridae) were dominant. Broad mesophilous (48 species) predominated in the hygropreference. 12 species are assigned as mesoxerophilous, and $9-$ mesohygrophilous. The main group is represented by hortobionts in habitat layer (49 species). Dendroand tamnobionts are represented by 11 species, and stratobionts are noted singly. The level of faunal similarity of heteropterofauna of different areas (Jaccard index) was 0.10 to 0.65 . The smallest similarity was noted between green areas of the city center and other urban cenoses $(0.10-0.12)$. The maximum indices were observed for parks and forest areas (0.65), and the average for meadows (0.35-0.44).

Key words: Heteroptera, Cimicomorpha, species composition, similarity, ecological groups, urban cenoses, Kharkiv, Ukraine. 


\section{Introduction}

The infraorder Cimicomorpha is the largest among the true bugs (Heteroptera) and is represented in the Palearctic fauna by almost 4,500 species in more than 650 genera and 10 families (Catalogue..., 1996; Kerzhner, Josifov, 1999). In Ukraine, this group includes six families with about 500 species (Putshkov and Putshkov, 1996). Almost all representatives of Cimicomorpha are terrestrial animals; most species (mainly representatives of the families Miridae, Tingidae) are herbivorous (some of these are dangerous pests of crops); many of them are predators (families Anthocoridae, Nabidae, Reduviidae) and control the abundance of various insects.

In Ukraine families of Cimicomorpha have been studied on various levels. The Reduviidae and Tingidae turned out to be well studied, that was published in two issues of "Fauna of Ukraine" (Putshkov, 1974, 1987). Some ecological and faunistic data about Cimicomorpha are provided, more often devoted to harmful species (mainly Miridae) (Puchkov, 1966, 1972, 1973) or to individual entomophagous (Putshkov, 1956, 1960, 1961, 1980 a, b; Putshkov, Putshkov, 1996). By the mid-1990s of the 20th century, publications on terrestrial bugs of the fauna of Ukraine practically disappeared, and only in the last few years of the current century some works on Heteroptera in different biotopes of Ukraine were published (Zhuravel et al., 2016; Markina et al., 2017; Polchaninova et al., 2019). At the same time, in all the above mentioned works, information about the true bugs is provided only for natural areas, and occasionally is devoted to some transformed ecosystems, usually to agrocenoses. Extremely fragmentary data on urban cenoses bugs (with a reference to the suborder as a whole or indications of single species) are available in some works only (Southwood, Leston, 1959; Putshkov, 1974, 1987; Klausnitzer, 1990).

In the last few years, we have started comprehensive studies on Heteroptera in conditions of megapolis (on the example of Kharkiv). The first extended ecological faunistic review of the true bugs of the infraorder Pentatomomorpha in the urban cenoses of Kharkiv City (Fedyay et al., 2018) was published, that provides information on 63 species of 53 genera and 11 families. The purpose of this paper is to study the species composition, spatial (storey) distribution and ecological structure of all true bugs of infraorder Cimicomorpha of Kharkiv City fauna.

\section{Material and methods}

The material was collected using a standard entomological net, Barber pitfall traps ( 0.2 liter plastic cups filled with $10 \%$ acetic acid solution), and hand collecting from the plants and soil litter. At each of five study plot, at least 200 swipes with the net were taken and 10-15 traps were set. In addition, bugs were collected during excursions throughout the city by examining individual plants and trees. Sampling was carried at intervals of 10-15 days in May-October, 2017-2018 at the following plots: "Peremoha Park", "Karpovskyi Sad", "Sarzhin Yar", meadowland along the Kharkiv River (Zhuravlivskyi Hydropark); plantings, lawns and public gardens of the city center and periphery; suburban forest plots (Kharkiv Lisopark). Their extended characteristics are given in our previous work on bugs of the Pentatomomorpha inforder (Fedyay, et al., 2018). To assess similarity of the bug species composition of the study plots, the Jaccard similarity index was used. For species richness, diversity and occurrence indexes such as Shannon, Pielou, Margalef and Berger-Parker (Lebedeva et al., 2004) using the PAST program were used. According to the abundance level (out of 5000 collected individuals), four groups of species were distinguished: abundant (more than $5 \%$ out of the total number of bugs), common (from 1 to $5 \%$ ), rare (from 0.1 to $0.99 \%$ ) and single (less than $0.1 \%$ ).

Classification of the infraorder follows the catalogues of bugs of Palearctic (Catalogue..., 1996; Kerzhner, Josifov, 1999). Characteristics of the ecological structure (by imago) is based on our own spieces occurrence data as well as literature sources (Southwood, Leston, 1959; Putshkov, 1966, 1972, 1973, 1974, 1987; Wagner, $1974 \mathrm{a}, \mathrm{b})$. Comparison of the peculiarities of distribution of the true bugs in Ukraine are examined using the catalog of V. G. and P. V. Putshkov (1996).

\section{Results and discussion}

Almost 70 true bug species of 44 genera and 6 families of the infraorder Cimicomorpha were registered in the urban cenoses of Kharkiv (table 1). Nine species turned out to be new for certain regions of Ukraine (Putshkov, Putshkov, 1996). So, for the first time in mainland of Ukraine, the species Xylocoris galactinus (Anthocoridae), previously known only in the Crimea, is indicated. The species Catoplatus nigriceps (Tingidae) known in the past in the western regions (Bukovina, Transcarpathia) and the Luhansk Region, as well as Stenodema holsata (Miridae) previously indicated for the western (Carpathians, Transcarpathia, Volyn, Podillia) and northern (Kyiv, Zhytomyr, Chernihiv Regions) territories turned out to be new for the forest-steppe zone of Ukraine. Trigonotylus ruficornis (Miridae) is also new for the entire Left-Bank territory of Ukraine. Formerly it was reliably indicated only for Transcarpathia (Putshkov, Putshkov, 1996). Most of 
previous findings under this name refer to the similar Tr. caelestialium. Apparently, the true range of Tr. ruficornis in Ukraine is much wider and its distribution requires special studies. Another five species of Miridae - Amblytylus nasutus, Deraeocoris lutescens, Globiceps flavomaculatus, Pilophorus perplexus, Notostira elongata were new to the Kharkiv Region. In Ukraine, they are widespread, indicated for most of the regions neighboring Kharkiv Region, and their findings were expected.

In general, currently, based on compiling our data and previously published information (Dekhtyaryova, 2002; Markina et al., 2018; Putchkov, 2013; Fedyay et al., 2018), the Kharkiv hemipofauna has 132 species (97 genera and 20 families), which is almost $15 \%$ of the total species composition of the suborder noted for the territory of Ukraine.

Significant differences were revealed in qualitative and quantitative characteristics of the Cimicomorpha which depended on the type of urban cenoses. Besides, it is worth mentioning, that comparison of individual species abundance or ecological group when the data were obtained by different sampling methods is quite complicated. Therefore, the classification of families and species according to their occurrence and abundance, correlation of different ecological groups presented in this paper are relative, since they are based on the averaged data.

In terms of taxonomic composition, the family Miridae was the richest -46 species of 29 genera. On the level of individual abundance, it made up more than $90 \%$ of all collected Cimicomorpha (table 1). Five species were numerous, only three of them appeared to be eudominant: Adelphocoris lineolatus, Notostira elongata and Stenodema laevigata, dominated in almost all urban cenoses (12.3-33.3 \% of the total number of bugs). Eight species are classified as subdominants in many urban cenoses; among them Adelphocoris seticornis, Lygus rugulipennis, Polymerus vulneratus, Stenodema calcarata and Stenotus binotatus are more frequent (table 1). Another ten species of capsid bugs are registered as sporadically not rare in individual urban cenoses, although their total quantitative part among the entire infraorder ranged from 0.2 to $0.8 \%$.

Typical representative of the urban bugs is the Nabidae family, although in both species and number they are significantly inferior to Miridae. A total of 9 species from 4 genera was recorded, which amounted to $7 \%$ of the Cimicomorpha abundance (table 1). Numerous species were absent, and three species from the genus Nabis (1-3\% of the total number of infraorder) were assigned to common ones (in some cenoses). Two species were rare but constantly occurring (Himacerus apterus, Nabis limbatus), and the rest were registered as occasional ones (table 1).

The family of lace bugs (Tingidae) is represented by 8 species from 6 genera (about $1 \%$ of the total bug abundance), and only Dictyla echii and D. rotundata are sporadically registered as common ones (table 1). The other species were noted as single, however, it should be noted that such low rates for some of them are due to difficulties in collection, hidden lifestyle, and small size of them.

Among the flower (Anthocoridae) and assassin bugs (Reduviidae), three and two species, respectively, were registered. All of them were found singly and only in some of cenoses. Only one species of bed bugs - Cimex lectularius (Cimicidae) has not been noted in open urban cenoses, but it is common one in some living quarters (more often in hostels). This species is a typical mesophilic synanthropic hematophagous, and the determination of its level of abundance and occurrence requires special counts, which was not our task.

On the whole, among 69 registered Cimicomorpha species, about 20 species can be referred to the common ones, four of them are abundant, and 14-16 are sporadically not rare. Other bugs (about $70 \%$ of the species composition) are noted as rare (about 10) and occasional (about 40 species) ones.

The ecological structure of the Cimicomorpha of Kharkiv is also specific due to variable conditions of the urban cenoses (tree and shrub associations, lawns, public gardens, meadows, waste lands, other plantings, etc.). 


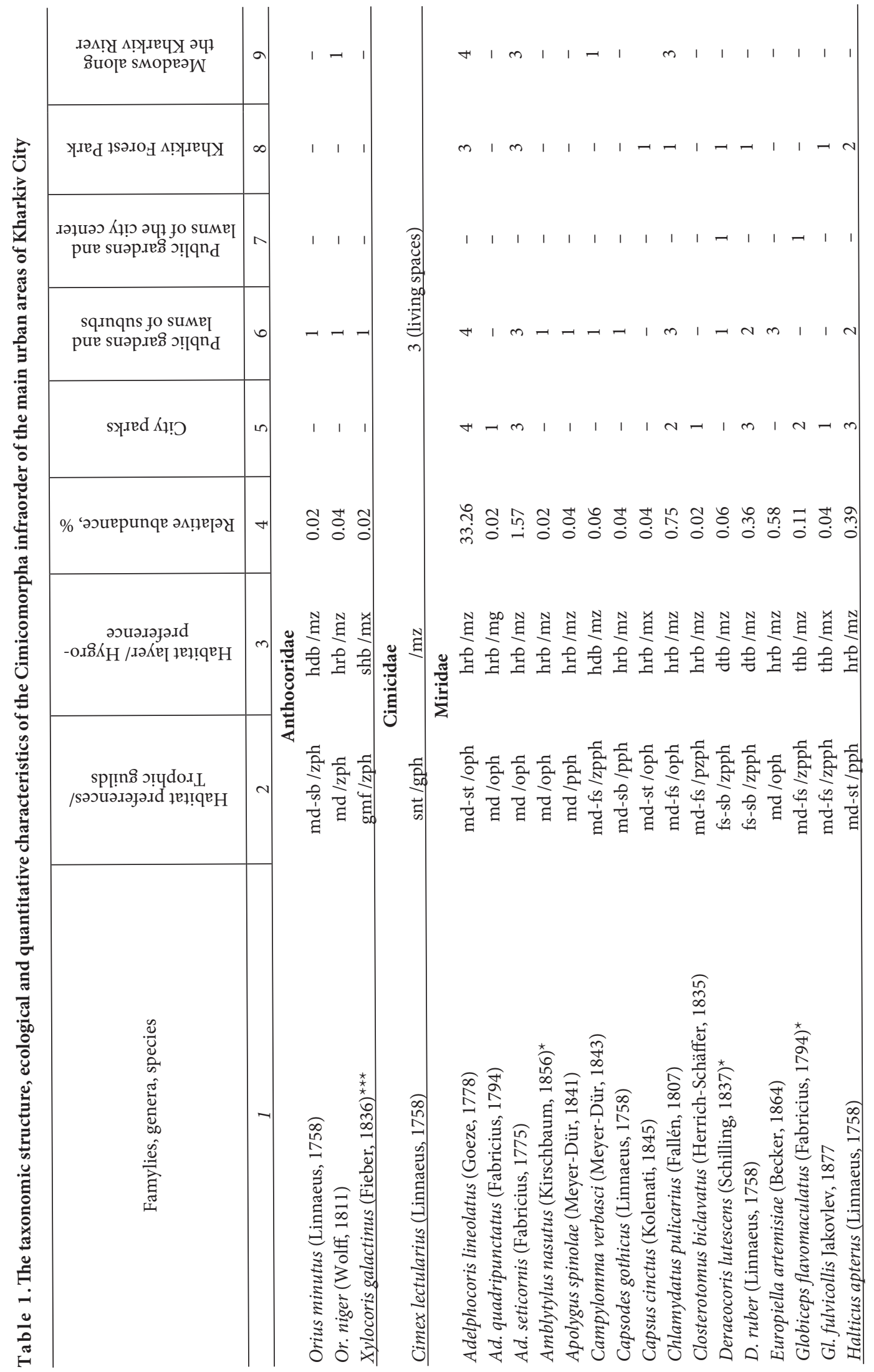




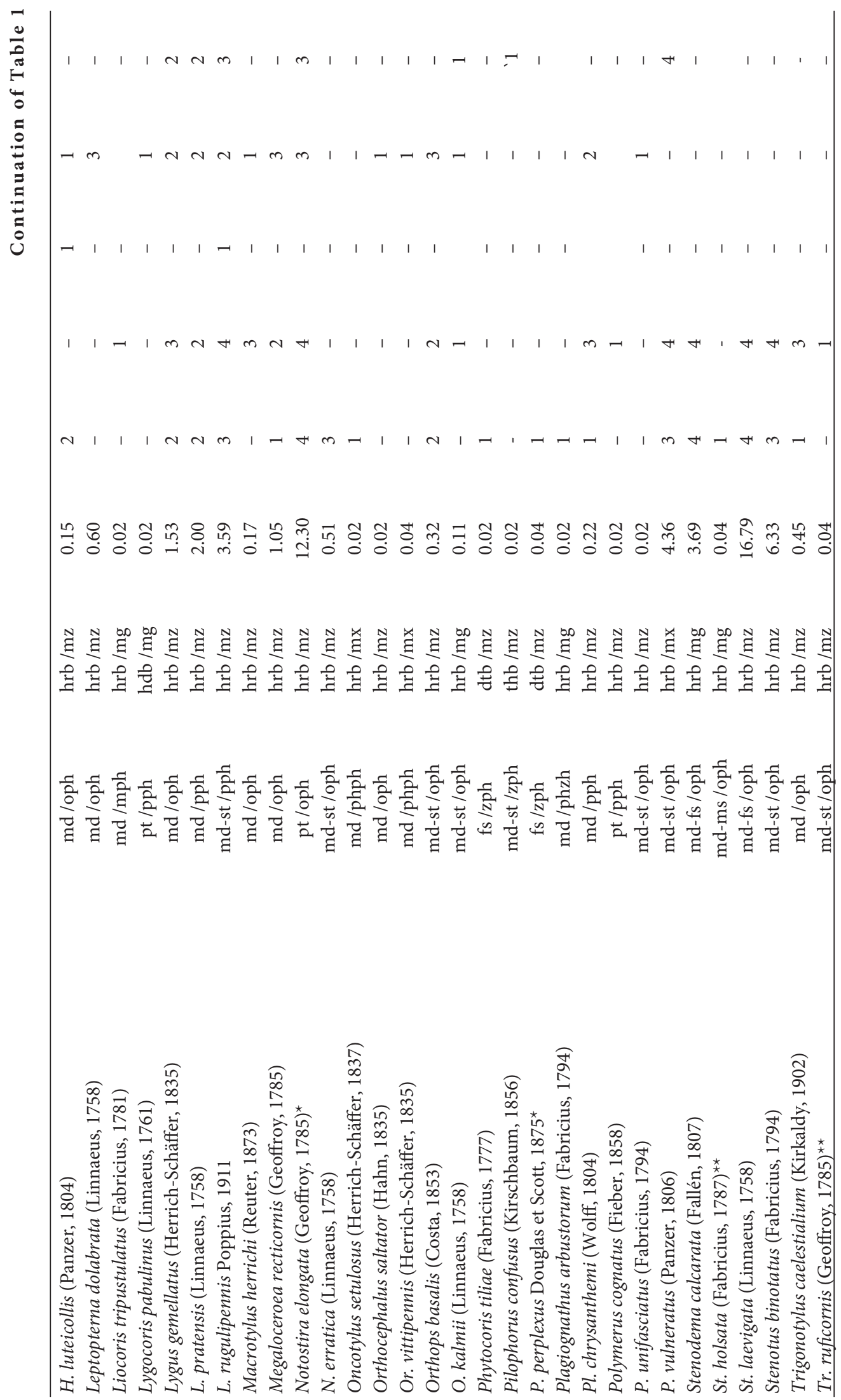




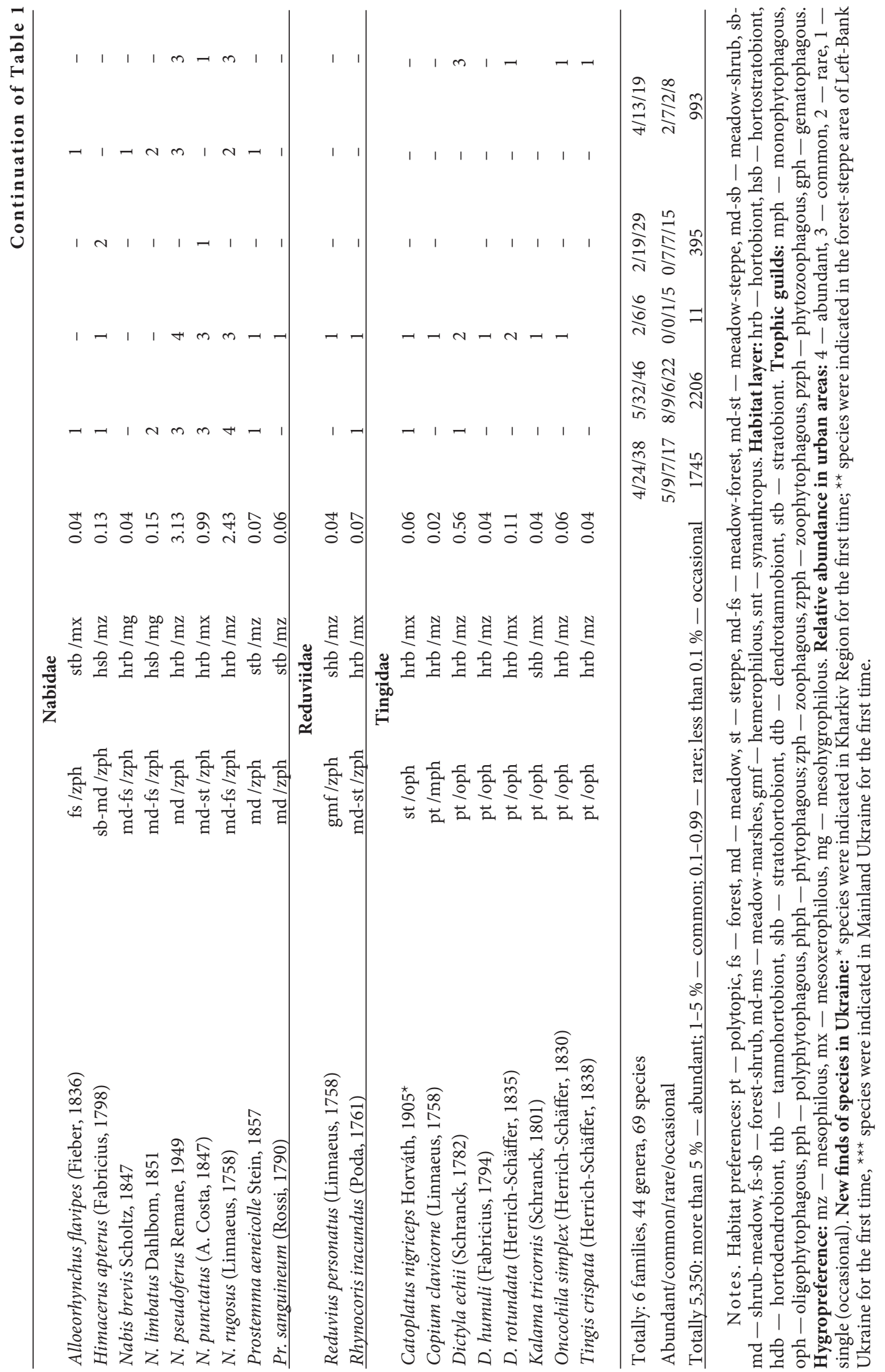


In terms of habitat preferences (table 1, fig. 1), most Cimicomorpha species are represented by a meadow group in the broad sense (inhabitants not only of typical meadows but of steppe-like or sparse meadow-shrub plots as well). In total, about 50 species of this group are registered, among which a half is common at most of plots. The most numerous representatives of the group include some capsid (Adelphocoris lineolatus, Lygus rugulipennis, Polymerus vulneratus) and damsel (Nabis pseudoferus) bugs; the total amount of them reached more than $60 \%$. Generalist species (eurytopic) registered in most urban cenoses are numerous. In total, 10 species of this group were recorded (mainly Miridae), but from them Notostira elongata dominated quantitatively (relative abundance accounted for almost $13 \%$ of the entire infraorder) (table 1, fig. 1). The forest group (with the subgroups of forest-meadow, shrub and forest-marsh elements) is represented by 15 species (about $8 \%$ of the total abundance of bugs). Among them, five species (mainly representatives of the genera Deraeocoris, Philophorus) are typical inhabitants of various forest stands, which amounted $1 \%$ of the total abundance of all true bugs. However, transitional groups (meadow-forest and meadow-shrub) sometimes were numerous (about 10 species): species of genus Stenodema, Nabis rugosus and, sporadically, Himacerus apterus prevailed. Two representatives of the hemerophilous group (species preferring disturbed habitats created by humans) were found singly (table 1, fig. 1). Among them, a certain faunistic interest is found in the parks of the thermophilous, widespread flower bug Xylocoris galactinus (Anthocoridae), indicated for manure-heaps in hot-beds, stack straw, granaries where temperature is quite high (about $30^{\circ} \mathrm{C}$ ) (Southwood, Leston, 1959).

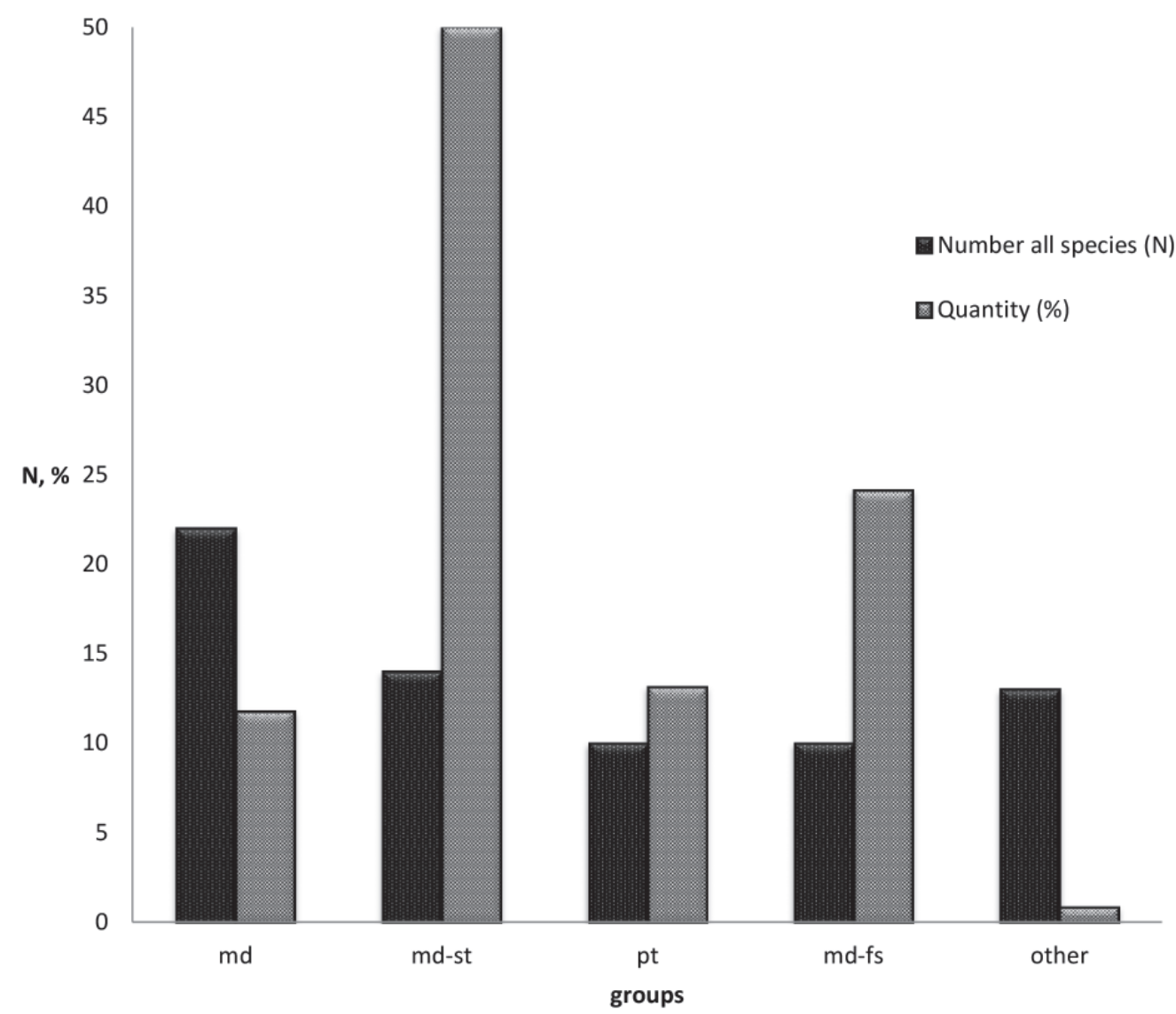

Fig. 1. Ratio between main biotopic groups of true bugs in terms of number of species and relative abundance (\% out of the total number of true bugs). Names of groups in acronyms are the same as in the table 1. 
Representatives of other biotopic groups are registered as occasional ones. It should be noted that the occurrence of certain species in a particular cenoses is determined by the presence of food supply, and to a lesser extent by the type of biotope.

According to the analysis of the trophic structure, Cimicomorpha species belong to herbivorous (mostly Miridae, all Tingidae) and zoophagous of different specializations (some Miridae, all Nabidae, Anthocoridae, Reduviidae) (table 1, fig. 2). Among the herbivorous (all together 45 species), oligophagous are predominated ( 32 species; almost $85 \%$ of the total number of all true bugs). There were significantly fewer polyphagous ( 7 species, about $6 \%)$. Monophagous and species with insufficiently clarified trophic preference, represented by two single species each (fig. 2). Among the herbivorous group, 17 species turned out to be common, four of them (Adelphocoris lineolatus, Notostira elongata, Stenodema laevigata, Stenotus binotatus) dominated in most biotopes. Typical zoophagous are represented by 17 species (7 \% of the total number), phytozoo- and zoophytophagous by seven species (about $1 \%$ abundance). From them only 4 species were sporadically subdominants.

An analysis of the heteropterofauna based on the species hygropreference showed prevalence of the broad mesophilous ( 48 species, more than $90 \%$ of the abundance of the whole group), almost 20 of them were abundant and common ones in urban cenoses of Kharkiv (table 1, fig. 3). Relative mesoxerophilous include 12 and mesohygrophilous - 9 species. But only two species of these (Polymerus vulneratus, Stenodema calcarata) are registered as common.

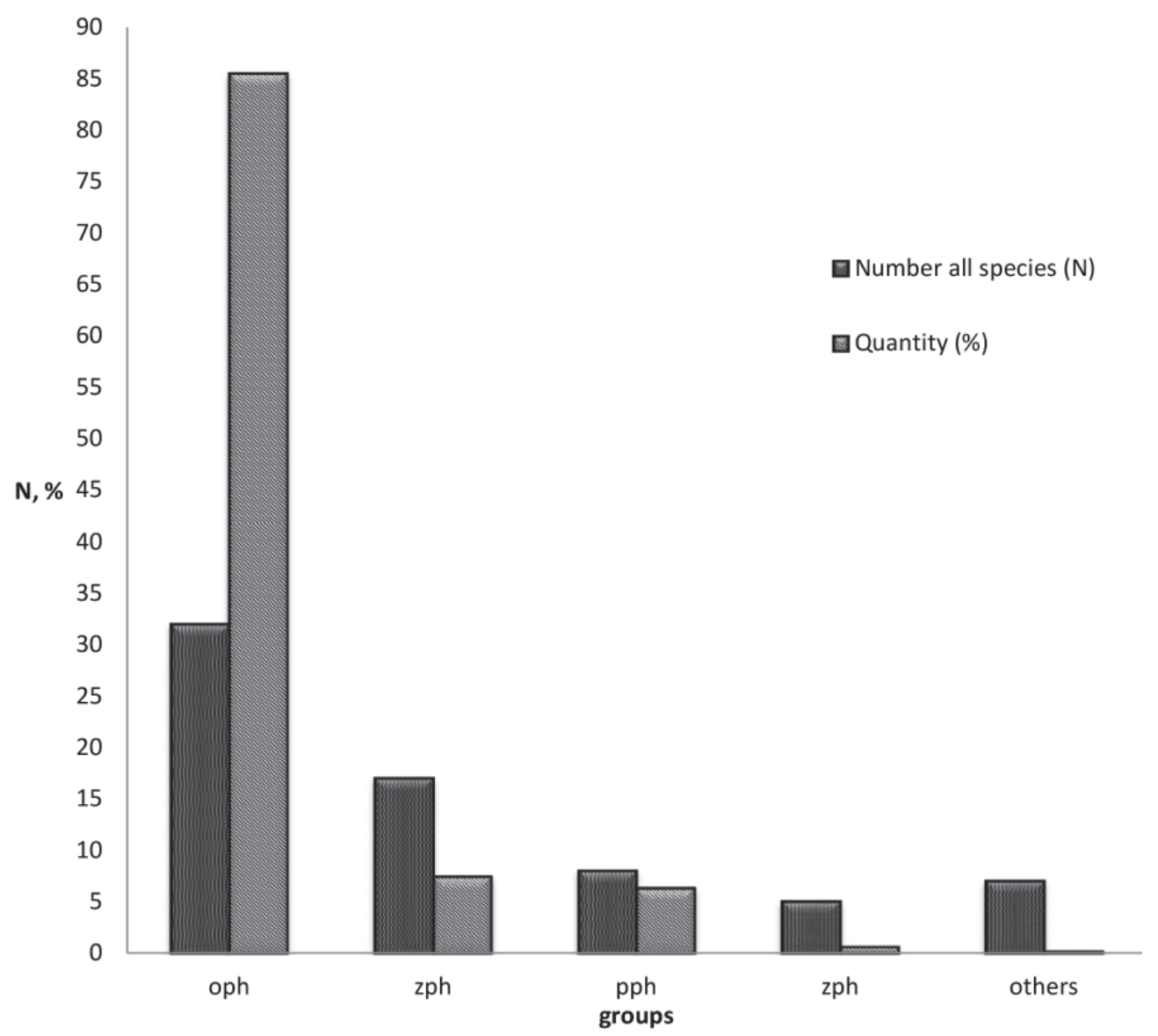

Fig. 2. Ratio between main trophic groups of true bugs in terms of number of species and relative abundance (\% out of the total number of true bugs). Names of groups in acronyms are the same as in the table 1. 


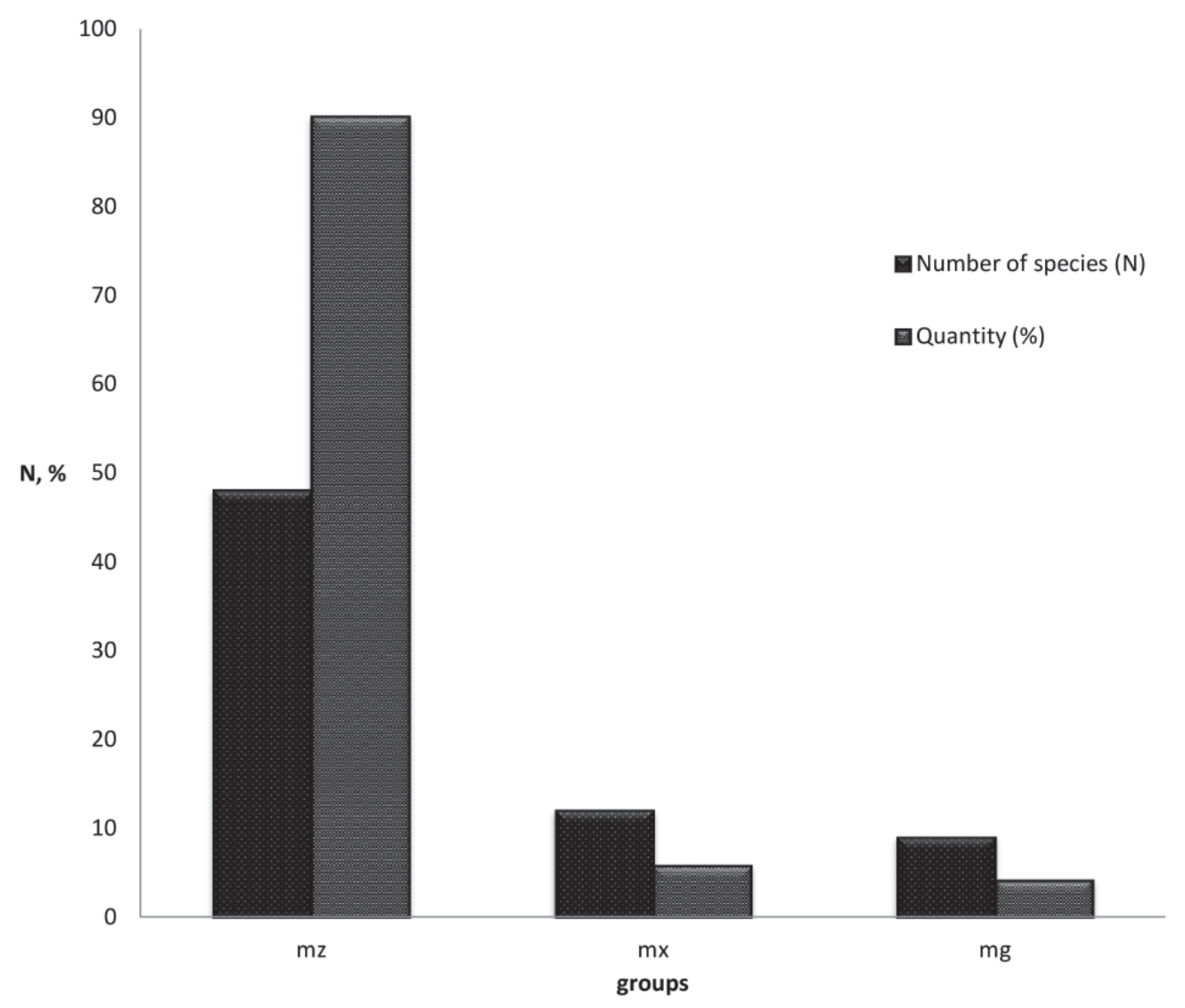

Fig. 3. Ratio between hygropreference of main groups of true bugs in terms of number of species and relative abundance (\% out of the total number of true bugs). Names of groups in acronyms are the same as in the table 1.

According to preferred habitat layer, eight groups of Cimicomorpha are selected (table 1). The typical hortobionts (inhabitants of grass and other low plants) prevail - 49 species, almost $98 \%$ of the total abundance. The true bugs found in trees and shrubs (dendro- and tamnobionts) are represented by 11 species, and transitional groups (stratohorto-, stratotamnobionts, etc.) by one to three species (table 1). Typical stratobionts (inhabit on surface of soil and detritus) include two solitary species of damsel bugs (Nabidae).

Thus, the aforesaid evidence indicates that typical bugs of urban cenosis are meadow hortobionts, broad mesophilic oligophagous, i. e. - environmentally plastic species, well adapted to living in the city.

Differences in ecological characteristics and in true bug species composition resulted in significant differences in their faunal similarities at the study plots (tables 1,2$)$. The largest number of species $(38-46$, up to five of them were dominants) was recorded in urban parks and slightly disturbed green areas of the suburbs. The high diversity of the species composition in these urban cenoses is due to the greater mosaicity of microstations (varied tree, shrubby, and grassy vegetation, a sufficient number of shaded and open areas, including those slightly susceptible to recreational pressure). The ratio of ecological groups in these areas did not differ much from the general indicators for urban cenoses as a whole. Polytopic and meadow (in the broad sense) hortobiont mesophilous species dominated, mainly from the families Miridae and Nabidae. 
Table 2. Species similarity (Jaccard index) and quantitative characteristics of hemipterofauna in main urban areas of Kharkiv City

\begin{tabular}{|c|c|c|c|c|c|}
\hline Urbocenoses & City parks & 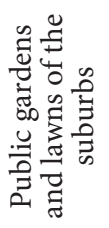 & 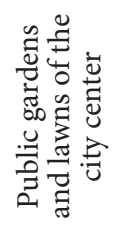 & 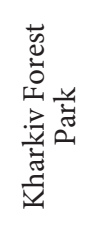 & 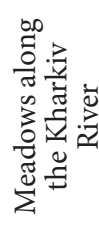 \\
\hline City parks & - & 0.43 & 0.10 & 0.65 & 0.35 \\
\hline Public gardens and lawns of the suburbs & $26 / 86^{*}$ & - & 0.10 & 0.44 & 0.43 \\
\hline Public gardens and lawns of the city center & $4 / 45$ & $5 / 53$ & - & 0.12 & 0.12 \\
\hline Kharkiv Forest Park & $24 / 61$ & $21 / 69$ & $3 / 28$ & - & 0.41 \\
\hline Meadows along the Kharkiv River & $16 / 62$ & $21 / 70$ & $3 / 29$ & $13 / 45$ & - \\
\hline \multicolumn{6}{|c|}{ Average value $=0.32$; coefficient of variation $C_{v}=58 \%$} \\
\hline
\end{tabular}

${ }^{\star}$ In the numerator - number of species; in the denominator - amount of all species in both urbocenoses.

In areas of the city center, subjected to a stronger anthropogenic press, adjacent to large housing estates and industrial enterprises, a decrease in species diversity indicators was noted. 6 species are registered here, only Himacerus apterus is classified as rare, and the other are solitary ones (table 1).

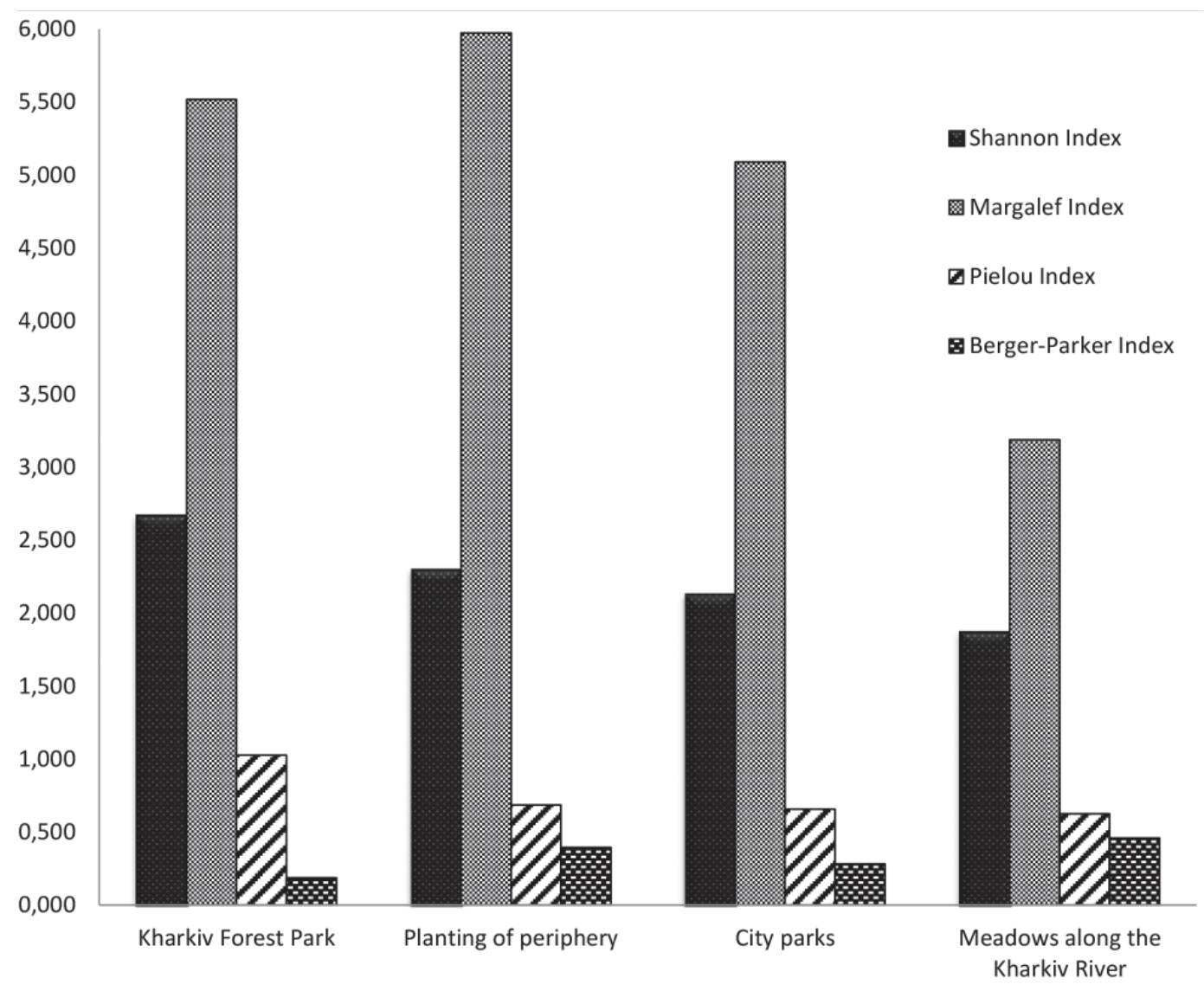

Fig. 4. Indicators of hemiptera biodiversity in main urbocenoses of Kharkiv City. 
Within the Forest Park, 29 species of true bugs were recorded, and in the meadows along the Kharkiv River - 19 species (about $20 \%$ of the total abundance of bugs); their number in these areas was an order of magnitude lower than in parks and green areas of the suburbs. 8 and 10 species, respectively, are assigned to the common ones in these areas, of these two species were abundant (Adelphocoris lineolatus, Polymerus vulneratus). The decrease in species diversity in forest biotopes can be explained by the depletion and even partial absence of grassy vegetation, significant density of trees and shaded areas. This, apparently, is an unfavorable factor for the habitat of many species (especially hortobionts), the richness and occurrence of which is sharply reduced, compared to even city parks. Floodplain meadows in the city are subject to significant recreational press, especially in the late spring and summer periods, which in turn also determined a certain depletion of heteropterofauna here.

The above mentioned differences in indices of diversity of Cimicomorpha at the study plots resulted in different level of faunistic similarity (table 2). Thus, the Jaccard index ranged from 0.10 to 0.65 (with an average value of only 0.32 ). The smallest similarity is observed between the green areas of the city center and other urban cenoses $(0.10-0.12)$. The maximum similarity indices were obtained when comparing the heteroterofauna of the city parks and suburban forest (0.65), and the middle level of similarity - meadows with most urban cenoses (0.35-0.44). The average value of Jaccard index variation (58\%), to a certain extent confirms the significant differences in the composition of the heteropterofauna of the examined plots. All the above-mentioned may also mean a weak association of particular bug species with certain urban biotopes.

A comparison of faunistic data between Cimicomorpha and Pentatomomorpha infraorder (Fedyay et al., 2018) in urban cenoses of Kharkiv showed their similarity in most indicators (from $0.04 / 0.07$ to $0.52 / 0.68$ with an average value of 0.27 for Pentatomomorpha and from $0.10 / 0.12$ to $0.35 / 0.65$ with an average value of 0.32 for Cimicomorpha). The least similarity was noted between the green areas of the city center and most of other plots. However, a comparison of the hemiperofauna of meadows and city parks showed higher rates for Pentatomomorpha (0.52) than Cimicomorpha (0.35). In pair-wise comparison of other plots, the Jaccard index ranged from low to medium (0.10-0.42).

The analysis of the main indices of species diversity of Cimicomorpha showed their low significance, in all urban cenoses (fig. 4, table 3). In most cenoses, the Shannon index ranged from 2.13-2.67, and the Pielou's uniformity degree was $0.66-1.03$ (fig. 4). The same was noted in Margalef species richness and Berger-Parker dominance indices. These indicators were slightly higher in Forest Park, despite the relatively lower abundance and poor of species composition in comparison with other urban cenoses (fig. 4). The minimum indices of species diversity (Shannon, Margalef $-2.13-2.30$ and 5.10-5.98,

Table 3. Indicators of hemipterofauna biodiversity in herpetobium of urbocenoses of Kharkiv City

\begin{tabular}{l|c|c|c|c|c}
\hline \multicolumn{1}{c|}{ Diversity indicators } & City parks & $\begin{array}{c}\text { Public } \\
\text { gardens and } \\
\text { lawns of the } \\
\text { suburbs }\end{array}$ & $\begin{array}{c}\text { Public } \\
\text { gardens and } \\
\text { lawns of the } \\
\text { city center }\end{array}$ & $\begin{array}{c}\text { Kharkiv } \\
\text { Forest Park }\end{array}$ & $\begin{array}{c}\text { Meadows } \\
\text { along } \\
\text { the Kharkiv } \\
\text { River }\end{array}$ \\
\hline Total amount of species & 39 & 47 & 6 & 34 & 23 \\
Total amount of genera & 25 & 32 & 6 & 21 & 16 \\
Margalef Index & 5.091 & 5.975 & 2.085 & 5.519 & 3.188 \\
Shannon Index & 2.13 & 2.298 & 1.642 & 2.667 & 1.87 \\
Pielou Index & 0.6574 & 0.6856 & 1.5769 & 1.0270 & 0.6254 \\
Berger-Parker Index & 0.2831 & 0.3953 & 0.3636 & 0.1873 & 0.4592 \\
\hline
\end{tabular}


respectively) were found in the meadows too. In these biotopes, a higher dominance of individual species was also noted, that is confirmed by the Berger-Parker index (0.46 versus $0.19-0.39)$, less by the Pielou evenness index ( 0.63 versus $0.66-1.03)$ in other urban cenoses (fig. 4). The degree of species diversity of the heteropterofauna in the city center urban cenoses could not be established, due to the extremely low number of single species of true bugs here.

\section{Conclusions}

During our researches, 69 species from 44 genera and 6 families of Cimicomorpha infraorder have been registered in the urban cenoses of Kharkiv City. Together with the studies conducted earlier (Fedyay et al., 2018), the total number of taxa in urban cenoses currently accounts for 132 species (47 genera and 11 families), that amounted to almost $15 \%$ of the entire terrestrial heteropterofauna of Ukraine. For the first time Xylocoris galactinus is recorded from Mainland Ukraine; Catoplatus nigriceps and Stenodema holsata - for forest-steppe zone; Trigonotylus ruficornis - for all Left-Bank. Five species - Amblytylus nasutus, Deraeocoris lutescens, Globiceps flavomaculatus, Pilophorus perplexus, Notostira elongata are new to Kharkiv Region.

The family Miridae - 46 species of 29 genera (about $90 \%$ out of total collected bugs) was the most rich in species and individual numbers, while Nabidae ( 9 of 14) and Tingidae (8 species of 6 genera, almost $10 \%$ of the abundance) were less represented. About 20 species are assigned to the dominants ones, of these four are most abundant, and 14-16 are sometimes common. The other Cimicomorpha (about $70 \%$ of the species composition) are noted as rare ones (about 10) and random (about 40 species).

In terms of habitat preferences, about 40 species (of these 4 are abundant) are represented by meadow individuals (almost $60 \%$ of the total number). Ten species are classified as polytopic (more than $8 \%$ of the abundance), but only Notostira elongata dominated quantitatively. The forest group (including subgroups of forest-meadow and forest-shrub individuals) is represented by 15 species (about $12 \%$ out of total collected bugs). Herbivorous (45 species, most of Miridae, all Tingidae ones) and zoophagous of different specializations (Nabidae, Anthocoridae, Reduviidae, some Miridae) were dominant among the trophic groups. Among herbivorous species, oligophagous prevailed (32 species; almost $85 \%$ of the total number of bugs); polyphagous are represented by 7 species (about $6 \%$ ), and monophagous - by only two species. 24 zoophagous of different specializations are registrated ( $8 \%$ of the total number), 4 species are registered as sporadically dominants ones. Broad mesophilous ( 48 species, more than $90 \%$ of the total amount) predominated and almost 20 from them were abundant .12 species are assigned as mesoxerophilous, and 9 - mesohygrophrophilous, only two species turned out to be abundant ones. The main group is represented by hortobionts in habitat layer (49 species, almost $98 \%$ of the total amount of bugs). Dendro- and tamnobionts are represented by 11 species, and 1-3 representatives are assigned to transitional groups (stratohorto-, stratotamnobionts, etc.). Two single species are recorded as typical stratobionts.

The variety of ecological characteristics of true bugs also determined the significant differences in their faunal similarity, abundance and structure at the study plots. The largest number of species (38-46, of these 5 are dominants) was recorded in the city parks and green areas of the suburbs. Only 6 species are registered in the city center. Within the Forest Park, 29 species were recorded, and in the meadows along the Kharkiv River - 19 species, the abundance of which turned out to be an order of magnitude lower than in parks and green areas of the suburbs.

The level of faunal similarity (Jaccard index) was 0.10 to 0.65 . The smallest similarity was noted between green areas of the city center and other urban cenoses $(0.10-0.12)$. The maximum indices were observed for parks and suburban forest areas (0.65), and the 
average for meadows and most of other urban cenoses (0.35-0.44). The aforementioned may indicate a low similarity of the heteropterofauna of individual urbanized biotopes. The analysis of the main indices of species diversity showed their low significance, indicating some oligodominant heteropterofauna in all urban cenoses. A short comparison of the faunistic data for Cimicomorpha and Pentatomomorpha in urban cenoses of Kharkiv showed their similarity in most indicators.

The authors are sincerely grateful to A. N. Drogvalenko (Museum of Nature of KhNU) for substantial help in identifying most of the Heteroptera species, as well as to Professor A. V. Putchkov for the faunistic and ecological consultations concerning particular species.

\section{References}

Catalogue of the Heteroptera of Palearctic Region. 1996. Cimicomorpha I. Aukema, B., Rieger, Ch., eds. 2, 1-346.

Fedyay, I. A., Markina, T. Y., Putchkov, A. V. 2018. Ecological and faunistic survey of the true bugs of the infraorder Pentatomomorpha (Hemiptera) in the urban cenoses of Kharkiv City (Ukraine). Biosystems Diversity, 26 (4), 8-13.

Kerzhner, I. M., Josifov, M. 1999. Miridae. In: Catalogue of the Heteroptera of Palearctic Region. Cimicomorpha II. Aukema, B., Rieger, Ch., eds. 3, 1-557.

Klauzhitser, B., 1990. Ecology of the urban fauna. Mir, Moscow, 1-248 [In Russian].

Lebedeva, N. V., Drozdov, N. N., Krivolutsky, D. A. 2004. Biological diversity and methods for its assessment. Humanity center VLADOS, Moscow, 1-432 [In Russian].

Markina, T. Yu., Gramma, V. M., Sirenko, V. O. 2017. Faunistic review of the bugs (Heteroptera) of the "Stone Graves" Reserve. Proceedings of the "Kamiany Mohyly" department Branch of the USNR of NAS of Ukraine. 4. Dyke Pole, Zaporizhzhia 269-277 [In Russian].

Markina, T. Yu., Putchkov, O. V., Fedyay, I. O. 2018. New and little-known species of the bugs (Insecta, Heteroptera) of fauna of Ukraine. Biology and valeology, 20, 43-48 [In Ukranian].

Polchaninova, N., Savchenko, G., Ronkin, V, Drogvalenko, A., Putchkov, A. 2019. Summer fire in steppe habitats: long-term effects on vegetation and autumnal assemblage of cursorial arthropods. Hacquetia, 18 (2), 213-231.

Putchkov, A. V. 1980 a. Peculiarities of biology of damsel bugs. Plant protection, 4, 44 [In Russian].

Putchkov, A. V. 1980 b. Distribution of species of the Nabis ferus L. group (Hemiptera, Nabidae) in natural biotopes and agrocenoses of some regions of the Black earth zone. Vestnik Zoologii, 4, 89-92 [In Russian].

Putshkov, P. V. 1987. Reduviidae Latreille, 1807 - assassin-bugs. Fauna of Ukraine. Kiev, 21 (4), 1-332 [In Russian].

Putchkov, P. V. 2013. Invasive true bugs (Heteroptera) establishedin Europe. Ukranian entomological journal, 7 (2), 11-28

Putshkov, V. G. 1956. The main trophic groups of herbivorous Hemiptera and the changing of their diet in ontogenesis. Zoological Journal, 35 (1), 32-44 [In Russian].

Putshkov, V. G. 1960. Revision of Heteroptera species of the Ukrainian SSR. AS of UkrSSR, 3, 367-371 [In Ukranian].

Putshkov, V. G. 1961. Capsid bugs (Heteroptera, Miridae) of Poltava region. Proceedings of Institute of zoology AS of UkrSSR, 17, 71-85 [In Ukranian].

Putshkov, V. G. 1966. The main capsid bugs - pests of agricultural crops. Naukova Dumka, Kiev, 1-172 [In Russian].

Putshkov, V. G. 1972. Order Hemiptera (Heteroptera) - The Bugs. In: Insects and mites - pests of agricultural crops. 1. Insects with incomplete transformation. In: Hemometabola insects. Nauka, Leningrad, 222-262 [In Russian].

Putshkov, V. G. 1973. Poluzhestkokrylyye. In: Vrediteli sel'skokhozyaystvennykh kul'tur i lesnykh nasazhdeniy Ukrainskoy SSR. Kiev, 1, 323-352 [In Russian].

Putshkov, V. G. 1974. Stitbugs, Firebugs, Beetbugs, Flatbugs and Lacebugs. Fauna of Ukraine. Kiev, 21 (4), 1-332 [In Ukranian].

Putshkov, V. G., Putshkov, P. V. 1996. Heteroptera of the Ukraine: Check List and distribution. St Petersburg, 1-108.

Southwood, T. R. E., Leston, D. 1959. Land and water bugs of the British Isles. F. Warne \& CO. LTD, London \& New York, 1-436.

Wagner, E., 1974 a. Die Miridae Hahn, 1831, des Mittelmeerraumes und der Makaronesischen Inseln (Hemiptera, Heteroptera), Teil 1. Entomologische Abhandlungen herausgegeben vom Staatlichen Museum fir Tierkunde, Dresden 37, Suppl. (1970-1971), 1-484. 
Wagner, E., 1974 b. Die Miridae Hahn, 1831, des Mittelmeerraumes und der Makaronesischen Inseln (Hemiptera, Heteroptera), Teil 2. Entomologische Abhandlungen herausgegeben vom Staatlichen Museum fir Tierkunde, Dresden 39, Suppl. (1973), 1-421.

Zhuravel, N., Polchaninova, N., Lezhenina, I., Drogvalenko, A., Putchkov, A. 2016. Preliminary survey of the ground-dwelling arthropods of the flood-plain meadows in the southeast of Poltava region (Ukraine). Biological Bulletin of Bogdan Chmelnitskiy Melitopol State Pedagogical University, 6 (3), 5-17.

Received 4 October 2019

Accepted 25 February 2020 